\title{
EXPLORING THE PRESENT STATE OF SOUTH AFRICAN EDUCATION: CHALLENGES AND RECOMMENDATIONS
}

\author{
L. Maddock* \\ e-mail: Lelys.maddock@wits.ac.za
}

\section{W. Maroun*}

e-mail: warren.maroun@wits.ac.za

*School of Accountancy

University of the Witwatersrand

Johannesburg, South Africa

\section{ABSTRACT}

In the light of widespread concern about, and continual questioning of, South African education, this article aims to examine levels of literacy among learners and students in the primary, intersen and senior phases, in the attempt to understand and to address at least some of the issues in the high drop-out and failure rates at tertiary level. The writers suggest that there is no simple solution nor single strategy but that theory and actual practice working together may engender meaningful change. With this aim in mind, 17 stakeholders were interviewed and their responses recorded and carefully analysed.

Keywords: CAPS; OBE; strategies; structure of learning phases

\section{INTRODUCTION}

The current crisis in South African education is well documented with academic papers, teachers' journals and newspapers presenting shocking statistics of poor academic performance, undertrained teachers and teacher absenteeism (Carte Blance 2012; Jansen 2012; Metcalfe, Orkin and Jenny 2012; Tau 2012; Singh 2015). Many students are unable to cope with the complexity of coursework (Guthrie, Evans and Burritt 2014; Persson and Napier 2014; Wilmot and Merino 2015). Some of these problems can partially be attributed to the failure of Outcomes-Based Education (OBE) but there are other factors to consider.

The primary aim of this article is to examine the causes of the very high number of students leaving school before matriculation and the equally high failure rates in first and second years at universities (Wilmot and Merino 2015; Oosthuizen and Cassim 2016). To achieve this, the study does not engage directly with different teaching and learning strategies or education theory (for examples in this regard, see Felton, Dimnik and Northey 1995; Greenberg and 
Wilner 2015; Wilmot and Merino 2015). The researchers rely on seventeen in-depth interviews with educators and parents to provide a viewpoint on the current state of the country's secondary and tertiary education.

The research finds that similar (and sometimes identical) points are raised by interviewees. For example, the newly introduced CAPS system has done nothing to remediate the problems in OBE; teachers often chose the career for no better reason than it is the only option available to them; inadequate and inexpert teacher training, offering little or no practical engagement in classrooms or lecture rooms, creates an unstable teaching and learning environment.

An overwhelmingly positive note is the commitment to and love of education that so many teachers show: they believe fully that, with strong leadership from the National Department of Education and the Ministers, and internally strong management in schools and universities, the dire situation and lack of literacy can be addressed. No-one doubts that this will take time but no one doubts that it can be achieved.

This article is important for educators at all levels who are struggling with these problems and opens the door for future research in the search for strategies which will give students (at all levels) a fair chance of success. The researchers believe that problems cannot be tackled before they have been adequately identified and discussed.

The remainder of this article is structured as follows: The framework and literature review explain the National Curriculum Assessment and Policy Statement (CAPS) 2012, the aims of South African education policy and need for a different type of education and training. This is followed by the method, a discussion of the challenges being faced by the local education system and an exploration of the lack of student readiness. Possible strategies for improving South African education are provided before the findings are summarised and recommendations are provided.

\section{FRAMEWORK AND LITERATURE REVIEW}

There is much written about pedagogic theories and practices, educational psychology, the history of schooling, and there exists a plethora of grading scales, rankings of institutions of learning and even school budgets and buildings (for examples see Hoskin and Macve 1986; Hoskin and Macve 1988; Lawrence 2014). This article, however, focuses on the Minister of Basic Education’s English language policy document (Motshekga 2012) as its primary point of reference. 


\section{National Curriculum Assessment and Policy Statement 2012}

The Curriculum and Assessment Policy Statement (CAPS) replaces OBE and focuses on excellence and subject knowledge and demands a higher standard of performance from students (Wilmot and Merino 2015). The South African national curriculum is, according to the Minister of Basic Education, "the culmination of our efforts over a period of seventeen years to transform the curriculum bequeathed to us by apartheid” (Motshekga 2012). This suggests a definite correlation between education and political ideology, a matter this article has alluded to in the findings because educational methodologies, like all systems, develop from societal constructs, like education (cf. Foucault 1983; Hoskin and Macve 1986).

The Minister Motshekga herself forges the link between "Apartheid" and "transformation" in education (2012) and powerful examples from history exist. The authors cite "Veldskool” camps in South Africa during the era of Nasionale Christelike Onderwys (post 1948) which were attended by white learners only and which were founded on a strongly militaristic and Afrikaner nationalistic ideology. ${ }^{1}$ Similarly, Roman education in the Republic offered elementary schooling which was "not compulsory but almost universal for sons and daughters of Roman citizens” (Dilke 1976). The main focus was to inculcate the ancient values of "pietas", "gravitas” and “civitas” so as to produce proud, hard-working citizens for the State (Cary 1976). In Queen Victoria’s British Empire, although only the aristocratic and/or wealthy had access to higher education, children were generally taught patriotism and moral precepts by means of suitable maxims and fables. One example is the famous advice given to David Copperfield by the financially ruined Micawber,

"Annual income twenty pounds, annual expenditure nineteen nineteen six, result happiness. Annual income twenty pounds, annual expenditure twenty pounds ought and six, result misery." (Dickens 1850).

Madam Minister continues: “Ongoing implementation challenges resulted in another review in 2009 and we revised [the 2002 document] to produce this document” (Motshekga 2012). This policy (CAPS) focuses primarily on English First Language Grades 10-12, a most vital and important stage in a learner's school career, ideally opening the door to future academic studies or to training programmes to ensure "fundamental human rights and improve the quality of life of all citizens and free the potential of each person” (Motshekga 2012). The researchers question whether or not these doors are opened. 


\section{The stated aims of National Policy Document}

The general aims in the policy, issued during 2012, are clear:

- $\quad$ providing access to higher education

- facilitating the transition of learners from educational institutions to the workplace

- $\quad$ providing employers with a sufficient profile of a learner's competences (Motshekga 2012).

In the light of South Africa's 28 per cent unemployment rate, ${ }^{3}$ these are valid aims which are not being achieved overall. The policy espouses certain principles, for example, "critical learning”, which the authors and other experts understand to mean the creation/production/ training of critical thinkers. The policy elaborates: "[This is] rather than rote and uncritical learning of given truths” (Motshekga 2012, 4).

The policy further defines the "minimum standards of knowledge and skills ... at each grade [to] set high achievable standards in all subjects” (Motshekga 2012, 4). We understand then that the primary aim is excellence which, in the Minister's own words about the failure of OBE, and reflected in reality in the workplace, has not been achieved. CAPS focuses more on subject knowledge and is more structured and prescriptive so the authors carefully deconstruct answers concerning this system. These pose important questions and we also consider the status of the teaching profession itself (Malan 2000; Crouch and Vinjevold 2006; Wilmot and Merino 2015).

The aim of the article remains examining literacy, clearly in both its linguistic and numerical forms, as the means to knowledge and expertise. Words in documents often do not reflect the reality in the classroom, tutor room or lecture theatre. In addition, as persuasive as "holistic" education sounds, students are not a homogenous mass: we applaud the policy's recognition of "managing inclusivity [to ensure] that barriers are identified and addressed by all the relevant support structures within the school community including teachers” (Motshekga 2012).

\section{The adolescent learner}

Adolescence is the stage in human development which “... covers, in Western Society, the time from the age of twelve or thirteen until the early twenties” (Martorell, Papalia and Feldman 2013). Adolescence remains a turbulent and complex time in human life. Physical development, although important if we consider "holistic" education (Martorell et al. 2013), is not our focus 
but we aver that successful educational practice should allow for and reflect cognitive development (Lawrence 2014). Cognitive maturity, according to Martorell et al. (2013), "is reached when a person is capable of abstract thought”. This echoes the document's aim of creating critical thinkers and effective citizens (see Motshekga 2012).

Our findings show this is neither a simple process nor a speedy one, and experts believe that OBE resulted in poor academic standards and a lack of thought and effort. Stakeholders observe further that the overly prescriptive CAPS is also already a failure.

Adolescents are often viewed as struggling to define their role but, even in the face of peer pressure, many ambitions are clearly defined: rebel or conform; be accepted or rejected; succeed or fail; be employed or unemployed (Martorell et al. 2013). (In South Africa, the last is of great concern).

Since Madam Minister has stated that first language English policy and practice are designed to create higher order thinking (Motshekga 2012), we rely here on Martorell et al.'s (2013) belief that thinking and learning on a cognitive level mean that a student is increasingly capable of "hypothetic-deductive reasoning” (2013, 562), usually beginning around the age of 12. Wilmot and Merino (2015, 259) identify these skills as "analysing”, "evaluating” and "creating”. Given the opportunity and the guidance to gain these skills, the student should succeed. In other words, the adolescent should be able to look at possibilities, measure these, consider triggers and reach valid conclusions.

How should this come about? Martorell et al. (2013) emphasised the interaction between the individual and his/her environment. The researchers examined the negative opinions of the majority of interviewees concerning standards of education. (The home is not the focus of this article although its importance as environment is obvious.) A learner or student who is never challenged or is being awarded marks, for example, in groups, without effort, or one who struggles with language and numbers, will not, no matter that he/she has been "pushed through" (the general consensus of educators interviewed as discussed in the section dealing with challenges below ) for a number of years, be a thinker or a searcher after knowledge (Malan 2000; Crouch and Vinjevold 2006; Wilmot and Merino 2015).

There is, it seems, a real divide between policy and results: basic skills, moral values, work habits are stressed again and again (see findings) According to those participating in this study, learners/students should be united in achieving one goal: success but this does not grow from the idea that no effort is required.

The researchers present these observations in the findings. Although not the focus of this article, we acknowledge poverty, lack of education excellence, lack of empowerment, early 
sexual activity and the breakdown in traditional structures like family and religion. (Again, we see scope for future research.)

\section{On the need for differentiation}

Considering the importance of literacy as the basis for all education, we refer to Lawrence (2014). If education is to serve its purpose, differentiation is essential: we cannot speak of learners and students as a faceless, voiceless group, "the majority" (2014, 8). With this in mind, we have considered the personal reflections of Lawrence (2014) as he forges this link.

“... Accountancy is a human creation - just like language. [It is] a way ... of understanding the world ... and giving it purpose" (Lawrence 2014, 39). He further states that "no rules can cover all eventualities” (2014, 39) and that "all knowledge is perspectival” (2014, 40). By "perspectival", we understand that knowledge only comes to life through the prism of the student's own interests, abilities, beliefs and observations.

This iterates the need for different types of education and training. He points also to the student's role here, "I think the supervisor has to treat the project as a developmental opportunity and encourage the candidate to take increasing responsibility for the project" (Lawrence 2014, 42). This counters the movements to too little assessment and structure in OBE and the prescriptive nature of CAPS. As Lawrence $(2014,47)$ points out, "We develop routinized, habitualised ways of behaving, so we do not have to think”.

This observation is ever more relevant when students have poor or no grounding, struggle with the language of teaching and are filled with a growing sense of hopelessness. Education is not objective as its roots are political and cultural but it is imperative that systems are thoroughly researched, planned and piloted before implementation. Differentiation within phases and stages is a cornerstone, even before we consider a "holistic" approach or "intervention" to repair damage.

\section{METHOD}

The researchers did not use a grounded study approach to link the points made by interviewees with specific theoretical frameworks. Instead, a phenomenological approach is adopted where the aim is to explore and describe the challenges experienced by educators and parents and offer recommendations for improving the state of South African education (cf. Llewelyn 1996; Llewelyn 2003).

Detailed interviews with seventeen stakeholders are used to gain insights into the challenges facing the South African education system and provide normative recommendations. 
Interviewees were purposefully selected and included educators at a secondary and tertiary level and parents of learners in Grades 10-12 from three provinces (KwaZulu-Natal, Free State and Gauteng). This may result in a degree of result bias. For example, the opinions of a broad group of stakeholders, including policy-makers, students and boards of trustees/governance, are not taken into account. Nevertheless, selecting specific respondents ensured that research participants have direct experience with the local schooling system and are able to provide a detailed account of their experience with CAPS (see Creswell 2009).

Interviewees were invited to participate in the study by e-mail. To ensure a detailed discussion, respondents were provided with a list of open-ended questions (Appendix 1) at least three days before meeting with the lead researcher. Although this does increase the risk of participants providing a rehearsed response, it ensured more detailed responses (Rowley 2012). In addition, to avoid individuals dominating group-based discussions or respondents' feeling uncomfortable with expressing their views, the researcher guaranteed anonymity and scheduled a time to meet each preparer and auditor individually.

At the start of each interview, the lead researcher provided each participant with an information sheet explaining briefly the purpose of the study. The information sheet iterated that they consented to participate and to have their interview recorded.

Time was spent establishing rapport with participants and explaining that the research was being carried out for academic purposes only. In keeping with a semi-structured interview approach, the researcher avoided interrupting respondents. Where applicable, the researcher asked respondents to explain particular points or statements in different words, to give examples, or to speculate on whether or not their peers would hold similar views. This was designed to add to the detail of the discussion, ensure that the researcher was not misinterpreting responses and avoid "script coherent expressions” (Alvesson 2003).

The interviews lasted between 45 minutes and 2 hours and were digitally recorded. Each interview was transcribed and initial notes were made to summarise the responses to each of the interview points. These notes were compared and interviewees' responses were consolidated and summarised to identify specific challenges/weaknesses and recommendations. The final results are presented according to these broad theme headings (adapted from Oakes, Townley and Cooper 1998; Leedy and Ormrod 2001).

The data analysis and aggregation process involved the researcher reading each transcript carefully several times and reflecting on the points raised by interviewees. Initial results were generated and debated by the lead and support researcher and several colleagues. After approximately 50 per cent of the interviews were completed, a sense of saturation was obtained 
and no additional points were identified (adapted from Holland and Doran 1998; Maroun and Atkins 2014; Atkins and Maroun 2015).

\section{CHALLENGES}

\section{South African education at the present time ${ }^{4}$}

There was no deviation from the negative response about the general standard of education in South Africa. Many reasons were given to account for this failure but the reality in the classroom, tutorial room and lecture theatre is gloomy and a genuine feeling of hopelessness pervades. For example, interviewees used the following words when explaining the state of the local education system: "horrified” (3), "massive red flag” (4), "all the ... unnecessary things”, “imposing a First World principle on a Third World country” (7), "shoddy” (8), "shockingly low” (10), “learners are forced through” (11), “marks are manipulated” (12), “sad state” (13), “into the deep end” (14), “set up for failure” (15), and “a quick fix” (16).

Respondent 3, when asked to explain what specifically "horrified” her after moving back to teaching in South Africa having spent 20 years out of the country, replied, "Just seeing the state of our students. The lack of respect [and] the attitude."

When the researchers asked Respondent 7 to clarify her responses, she defined "unnecessary things", to be different forms of time-consuming paperwork which "take away teaching time". She also added that the introduction of CAPS was too sudden, the change too dramatic and the content too sophisticated for South Africa, "a Third World country”.

For example, the following point was repeated many times: “Officials [are] ignoring actual teaching and [are] focusing only on checking educators' files” [13]. Also laying blame at the feet of the Department of Education, Respondent 5 said she too felt that if thorough research and preparation were done, change might occur. She felt that if: "things can be streamlined, there's hope that could make a change”. The writers understand these responses as a need for a thorough re-examination of the current system.

\section{View of OBE}

Although some respondents saw some potential in OBE (in the hands of knowledgeable and committed teachers), all other interviewees felt that OBE had disadvantaged students in many serious, and perhaps irreparable, ways. In particular: the calibre of teachers entering the profession since 1994 is cause for concern. All respondents felt that too many enter the profession for the wrong reasons 
The majority of those interviewed spoke of "teachers with very limited knowledge” (12). A Grade Head, Head of Department and Deputy Chief Marker stated: “Teachers are giving marks to students who don't deserve it [sic] because they don't understand it [sic] themselves” (11). The consequence is that "kids [are] not learning conceptually but by rote: they can get A's with that” (13).

It seems that the poor levels of literacy among students is a sine qua non unless measures are put into place to upgrade educators themselves. It is clear that this contradicts the Department's defined pedagogic aims of following the principles of "active and critical learning” and "high knowledge and high skills” (Motshekga 2012). ${ }^{5,6}$ Respondent 4 summed up succinctly: “... specialist teachers and excellent resources must be available”.

When the interviewer asked respondents to elaborate about resources, a range of answers emerged but consensus is that the teacher is the primary resource. This substantiates the importance of the profession's status and the need for quality student-teacher admission and training. Respondent 2 defined the variable as "the teacher's knowledge, his/her ability to maintain discipline". ${ }^{7}$ This parent believes that expertise is in itself a powerful factor in a successful learning environment. Respondent 4 added that the "expert" educators will automatically gravitate forwards to the best schools. He summed up: "private schools have access to more resources, more money and so they are able to get better teaching staff”.

\section{Unprepared students}

All respondents blamed OBE for the high drop-out and failure rates in South Africa. Key issues identified are the lack of a strong foundation ${ }^{8}$ in primary school and the lack of structure and student accountability in secondary school.

All respondents were critical of OBE's reliance on group work, citing either "shared" marks or inaccurate assessment as reasons for failure. Respondent 9 said, "OBE was there just to pass the learners without any knowledge ... there were no formal tests, portfolio [tasks] were always open book”. This was echoed by many interviewees who voiced the following criticisms of the system:

"One child would do the project and everybody would get the same mark.” (R10)

"At meetings they [the appointed facilitators] would give us these stupid questions to do and say you have to teach this in class" (emphasis added). (R11)

These insights from Respondents 10 and 11 reflect a general concern about the failure to recognise and incorporate individuality, whether in a student or in an educator. This theme is 
further explored in the section on strategies below.

Further thought-provoking comments on the negative elements in OBE are included below. The writers chose to cite different stakeholders here: a parent, a secondary school principal and a lecturer in teaching and learning at tertiary level.

Respondent 15 spoke as both a parent with children in a top private school and as a university lecturer when he said that OBE "has taken the kid's [sic] creativity away ... that creativity is what leads to critical thought”. Respondent 16 summed up by saying that in the large state secondary school he heads, OBE has failed the junior grades:

"This year's Grade Nines (2015) are in the deep end. They arrived in a system where you needed $30 \%$ to pass and then overnight, and a long holiday (2014), come back and now you need 50\%.”

The last word goes to a senior lecturer at a top university who, although he has no direct teaching experience in OBE, provided a strong insight into the weaknesses detected generally in secondyear students who are products of the system. He said the first-year course he is teaching is "not a standard course in the sense that it's meant to be a foundation”. He added that the pass rate is high because "first year is mostly doable [sic] without too much effort" (15) but that rote learning is not knowledge and that actual understanding is lacking. He also spoke of serious cultural, economic and emotional problems resulting from the above. ${ }^{9}$

\section{Chaos in the classroom}

Respondents felt that the lack of structure and challenge in OBE, added to a policy which denies schools the right to discipline learners except by issuing detentions, has created a generally subversive student body. Conversely, they all also spoke of the minority who did apply themselves and so, passed but stressed that this lies in the individual's ability, norms and attitude, not in extrinsic factors.

Respondent 1 felt that, "Many of them felt that they were ready for a challenge and there was this vacuum, this disappointment”. She was of the view that this caused frustration, poor behaviour and frequent absenteeism. Respondent 9 agreed but also linked the poor behaviour of learners to the shortage of good educators: "Many promising young teachers are just giving up and resigning”. The consensus is that education has to guide students towards self-discipline, a desire to be excellent, and a respect for authority.

\section{CAPS}

Only two respondents had positive comments about the implementation of CAPS: all others 
answered with a resoundingly negative emphasis, the most repeated point being that the experience has made teaching/instructing more difficult but has not, in any way, raised the standard of education or improved actual literacy. Respondent 9 felt that "within 5 years, this might change" but there is no assurance that this will happen, given the current state of education. One interviewee said: "I can [now] see a goal in the questions asked (not so in OBE) but you need a full 5 years of guys (sic) going through this before a valid assessment can be made" (R2). Respondent 3 made the challenging point that CAPS "may be the answer because it's much easier for the teachers because it's all set out”. However, having considered class sizes and the administrative workload, she changed tack and stated, "No is the answer". Another educator went further:

"I haven't really changed teaching from OBE to CAPS because we've got a good teaching style [at his respected private school] and we weren't going to let the government mess that up.” (R4)

Respondent 7 added,

"I can't with confidence say that it [CAPS] has done anything besides put more pressure on learners to try and perform but you're still not really changing the underlying foundation.”

The point about weak foundations became a theme in the interviews as all respondents answered that the majority of learners and students are not ready for the next phase of their education because the basic skills and techniques and subject knowledge are lacking. The consensus was that no single system can right this. ${ }^{10}$ Respondent 7 continued that of great concern to her is the:

"reverse effect of CAPS" i.e. that "It becomes a case that you have people in senior management who will now try and encourage you to set tasks of an easier standard: let's drop the standard so that we can get $50 \%$."

The concern is that even many students who have been awarded A's and B's in the Senior Certificate Examinations struggle to achieve 50 per cent at university. Interviewee 8 shared her concern when she said,

"Teachers and principals particularly do not have any influence on what is going to go forward with CAPS" because "everything at that office ${ }^{11}$ is political."

Added to these stressors, many added concerns about learners and students with inadequate 
preparation "migrating” to $\mathrm{FL}^{12}$ English schools and universities without access to remediation or bridging classes. Respondent 9, although prepared to give CAPS a chance, said, "I must say ... I don't think it's better than OBE”. Another of her concerns is that HOD's have been told, “... these kids [sic] are at a disadvantage so you have to give them $15 \%$ more so the new $50 \%$ and the previous $40 \%$ remain the same”.

No-one defined or classified the students who needed "helping" (q.v.). The authors are acutely aware of the fact that the view may be seen as racist, sexist, religious bigotry but our context is actual levels of literacy in education. Respondents 12, 13 and 14 felt that CAPS does not encourage thinking and originality, and that the analytical skills needed in English and Mathematics have been abandoned. Of the CAPS approach, Respondent 12 said: "Everything is basically pre-listening and then regurgitating”. “... Even in the top schools, it’s encouraging learning rules at the expense of knowledge” (R13). One interviewee, speaking from a university perspective added, "My big issue with CAPs is at the end of Grade 12 CAPS process, students have not learnt the importance of failure ... so we are letting these students in with significant false expectations”.

The consensus is that CAPS has been implemented before the system was thoroughly researched and tested, according to the respondents, inadequately prepared so the change is a sham - a change in name only.

\section{READINESS}

For convenience sake, the article groups these findings into phases of education since the focus is on success or failure of students, i.e. having gained (or not) the skills and knowledge to move forward into the next modules of studies. There is no suggestion that the levels are the same but the focus of the article remains the Department's assumptions concerning readiness to progress through each stage from primary to General Education and Training (GET) to Grade 10-12 and to tertiary studies or training or to the workplace.

\section{Concerns of parent and educators}

Respondent 2 said, looking back at his daughter's twelve years of schooling, “I was happy with the way primary was and how they got her ready [for Grade 8]". He added, however, that considering his child's five years in secondary school, if he could have afforded to get her into a private school, he would have done it from high school.

Respondent 7, a senior English teacher in an IEB school, said of her own children's experience in the primary phase at the same school, that if she and her husband remain in South 
Africa, her children will remain in this school because "the ethos is very much about individuality and [the school] caters for [my] children's needs” academically and culturally and emotionally. She said this is not so in government schools (in which she previously taught) where "teachers have to try to get as many kids (sic) as possible to pass".

Respondent 10, with 20 years' experience in first additional language teaching in the Senior Primary phase in government schools in Gauteng, said that, although by the end of Grade 7, she had "taught everything that she had to teach so that they should have been ready, for most of them, $60 \%$ of them, it didn't even go in”. This she blamed unequivocally on the culture of, “I’m going to pass anyway”. (Respondent 5 from the Free State concurred almost verbatim although interviewees never met.)

As further explanation, we cite the actual experience of the lead researcher who, while teaching English FL to Matrics, was told by the subject facilitator that no learner can be given zero: "Give the mark you think the learner would get if he/she were present".

Respondent 10 also stressed the great difference between the State schools and her current work in an IEB private school where "the work ethic is good, the learners are well rounded and moral values are stressed daily”.

Respondent 17, a lecturer in a top South African university had much to say overall as she has all of her own three children in "good" government schools. Her youngest moved from a private special needs school to a "very good State school” but she feels that the financial outlay on the years in the private school was worth it as "there are not a large amount of remedial State schools and so we went private to give him the best possible chance to succeed”.

She was emphatic throughout the interview that "it [sic] depends on the school to a large extent". Her primary school child has the advantage now in a State school of "specialist educators who come in once or twice a year" to explain the exam process, CAPS terminology and to introduce learners to "a group of different learning styles they can try". However, the schools which are successful in fulfilling the aims in the literacy policy document are a small minority, a point which emerged in all interviews with stakeholders in secondary phase.

\section{Implications for tertiary education}

Principals, teachers and parents linked lack of readiness to failure in tertiary studies and/or training with poor primary schooling, even before problems in secondary schools evince themselves. Respondent 1 said, "Children come to high school and they know far too little. I find it a bit of an issue when my [secondary school] teachers have to give writing lessons on the board." She added, "So what have they done for seven years? You need to go to Primary 
school and kick some butt. My [Grade 8 Cycle test, Term 2 2015] and I'm the HOD, 5.8\% passed English.”

Considering the high-flown rhetoric and lofty aims of Madam Minister's policy document, the failure of OBE and CAPS from the perspective of those actively involved on a daily basis and the great need for skilled people in South Africa, such statistics are indeed worrying. From Grade 10 onwards, other serious problems were identified in both private and government schools.

Respondent 7 said, from the educator's perspective, "If you look at kids [Matrics] that do perform, you wonder if they are "ready" for tertiary simply because they've gotten (sic) the distinction”. Her understanding of actual literacy, in line with that of all other interviewees, is not just being able to read the words on the page, "the problem lies with the text or the underlying understanding of what's being said and very few are actually grasping that” (emphasis added). ${ }^{13}$ She added that the dire situation is aggravated because "literacy is seen as the job of the English teacher. Surely you can encourage literacy in all your subjects?”14

Respondent 11 saw two main problems resulting in a lack of readiness to progress: (1) "In Grade 9, learners are choosing subjects because they are told they must do Science and Accounting. A lot of them do not have that ability” and (2) “in Grade 12, learners cannot read, write or think. They won't get into tertiary because their level is so low.”15

Respondent 13 said that, in spite of "questions trying to be more problem-based”, because “the teachers are not at that level and Department and management are just raising the marks". Respondent 16 echoed this view that differentiation must be reintroduced because at this time, university is the only option and not everyone is academic.

Providing such schools and colleges will re-inforce the politically lauded diversity in South Africa, endorsing the authors' link between education and politics in the references to the Policy Document (Motshekga 2012). Respondent 17 concurred that tertiary level "requires you to analyse things by yourself and if you don't understand, it won't make any sense”. She based her observation on her teaching and research at a top university.

\section{Emerging concerns from the tertiary sector}

Respondents 6, 14, 15 and 17 looked at the readiness of their own tertiary level students in 2015 and earlier. All of them stated that their students were ill-prepared for the rigours of tertiary studies: a range of interesting insights emerged.

Respondent 6 said, “I don’t think in general that students are prepared for not even the next year of their undergrad [sic] degree, never mind higher degrees”. He continued that most 
of the students write "drivel, absolute nonsense”. This, of course, points to an inability to think critically. He said (repeatedly) that these failures are entirely the result of poor teaching even at tertiary level and he feels that language studies must be incorporated in all degrees if the situation is to improve (emphasis added).

Respondent 14, who is in charge of a programme to help first-year students to improve their literacy levels, said that the vast majority of students are not ready for tertiary studies but that the standard at university is being progressively "dumbed down to accommodate failures". He cited the following,

"Economics I is now multiple choice tests without negative marking so students can actually guess their way through a course and get 70\% and it doesn't mean 70\% because they actually know $30 \%$ of the material.”

He summed up,

"Students just come out of getting 7 distinctions in Matric [are] struggling to get $50 \%$ in their [June] exams.”

Respondent 15, gravely concerned about his first-year students, also cited poor reading/writing skills. In addition, he expressed concern about "pressures to lower the standard. The new thing is that we have to reduce the amount of content so you [sic] are lowering the standard, even though, it is not communicated like that.” When asked to clarify this point, he explained that, although the mandate did not refer in finite terms to lowering the standard of some courses, it is clear that thinner content and volume make fewer demands and take less time to research and study.

Respondent 17 reiterated poor levels of actual literacy and a dearth of critical thinking at tertiary level. When the researchers asked whether the situation can be remediated, she answered in the affirmative,

\footnotetext{
"but it needs to start right at the bottom and I think it needs to start with equipping the teachers with skills. They need to have an understanding of what they are teaching. There needs to be an encouragement with the children to think about things and explore and question the way things are done.” (R17, emphasis added.)
}

Overall, the authors are satisfied that the views expressed are based on the extensive experience and the obvious expertise of respondents. 


\section{STRATEGIES}

Many strategies were offered: few practical suggestions matched these. Points made often echoed one another and some respondents repeated their observations about South African education but, overall, answers were insightful.

For convenience sake, we have identified recommended strategies according to the weaknesses and problems discussed in Findings. All respondents repeated the gravity of the shortage of excellent educators; the escalating number of experienced, expert educators leaving the profession; an unwieldy and rigid CAPS system introduced without adequate research and testing, and low standards which do not reach the 50 per cent pass in English and Maths prescribed.

\section{Suggested hypothetical strategies}

Many suggested strategies were based entirely on emotions; we have included a few as a contrast to thoughtful and possibly practical strategies if (author's emphasis) the Ministers take note. Among hypothetical suggestions were the following:

1. “Revolutionise primary school” (R1)

2. "Parents must be involved and accept responsibility" (R2)

3. "Put less emphasis on Maths Literacy and just work harder" (R4)

4. "Give us one language and teach it properly" (R8)

5. "A school must have strong leadership" (R10)

6. "Employ a qualified psychologist in each government school” (R12)

7. "Make primary schools accountable" for the academic readiness of learners (R12)

8. "Stream teachers according to their training and ability" (R13)

9. "We have to teach students how to study", even at a tertiary level (R15)

The authors agree that the intensity of all respondents was palpable but that these suggestions would be difficult to convert into a plan of action.

\section{Practical suggestions}

\section{Screening and selection of prospective educators}

All but three respondents focused on the need for careful screening and selection of candidates applying to become educators. When we asked about the calibre of teachers entering the profession, these responses were, in varying degrees, all negative. Respondent 4 said, "A lot of people go into teaching because that is their only option”. 
When asked to elaborate, he explained that financial constraints and/or having failed other first-year courses resulted in many unmotivated candidates registering for teaching. He felt strongly as a Science graduate who afterwards, by choice, studied to teach, "If you're not good enough to get into Honours, then how can you be good enough to go and teach people?’

Echoing these sentiments, Respondent 8 said that if the status of the profession is improved and the criteria for acceptance are raised, many existing problems will be solved. "Recruit the best people to teach. Too many youngsters ... are just there to earn a salary and they [go] into teaching, thinking it is a half-day job with long holidays.”

Respondent 5 spoke of a lack of commitment and ethics in many young teachers, calling these "clock-watchers". She, as a Principal, is also alarmed by teacher absenteeism and the number of fellow-Principals who have had to take action against those who choose to make appointments during school hours when there is no emergency or life-threatening situation.

What became more and more clear to the authors as transcripts were analysed is that the teacher / tutor / lecturer / coach remains the most important resource in education and that the suggestion of careful selection, following academic, psychological and ethical guidelines is an excellent way forward.

The authors are basing "selection" on the individual abilities of candidates applying, for example, a love of reading and research and an excellent Senior Certificate symbol in languages should be an indicator of academic ability. (The same level of excellence would apply to other subjects.) Emotional intelligence is clearly seen in a candidate's involvement in the community through his or her school/ church/ temple/ mosque/ shul. Hours given are always included in the student's testimonial.

In answer to how to improve the status of education in our community at large and so attract "the best candidates", we again had similar suggestions from all respondents who see upgrading salaries and benefits as the top priority so that education can be brought into line with other professions. Respondent 8 said,

“The District Director and the Head of Department's office need to look at this ... and to pay attention to why so many good teachers are leaving for private institutions in this country and for foreign schools."

Respondent 16, a principal, summed up this concern as follows:

"The government must take it [education] seriously. Have a wage where they can live, which is better now but still because a secretary with no experience gets R20,000 per month which is more than an entry level teacher with a degree.” 
The importance of job satisfaction was a theme throughout Respondent 10 described the reality succinctly:

“No-one wants to be a teacher: there’s no respect for teachers anymore. It’s a thankless job.”

Educators, even at tertiary level, frequently spoke of teaching being regarded as a "soft" job, not a real profession at all. The writers suggest that this patronising view must be countered by excellence in the profession and a strong Department which supports and demands excellence.

\section{Internships}

A thought-provoking strategy mentioned by many was the internship/mentorship system which allows students to study and to gain practical experience as full-time teachers at the same time: some described this as “a kind of apprenticeship”. Most respondents, whether they had had personal experience of the system or not, felt that the current system of "academic" studies and a 3-week practical in no way prepares education students for the realities of the classroom or lecture room because interaction is lacking and working according to a checklist of lesson plans and files is useless when actually engaging during contact time.

Internships are not revolutionary as internship/articles are a long-standing element in respected professions like Medicine, Law and Accountancy. The support for internship from all respondents, except number 3, rests on their belief in experience, not just theory.

Respondent 8 said interns she has worked with "are better qualified to teach than those going through colleges” because they have actual experience and are more confident about asking and answering questions.

Respondent 14 looked at universities providing mentors in every faculty so as to "challenge students to think and guide them to find the stuff [sic]". ${ }^{16}$

Respondent 15, also at tertiary level, although he did not use the term "internship” insisted that we need to include practical skills (emphasis added). Like all other respondents, he added,

"Remediate the basics, appoint mentors." He did, however, add the proviso that "in internship/mentoring, a relationship needs to be built so mentoring with the right people could work very well” (emphasis added).

\section{Differentiation}

Respondent 16 said that the young teachers in the government school he heads “can't cope. Varsity hasn’t helped them. You need to work, you need to listen, you need to teach.” This was 
endorsed by respondent 17 who lectures at a top university and strongly, from her research, concludes that "experiential learning has become the most effective way to teach so it is the best way to learn to teach”.

This important (possibly controversial) but insightful strategy suggestion is what the authors have termed "differentiation"; the term is defined by the Oxford dictionary as "observe, ascertain or recognize the difference (in or between)". We have used this term throughout this section to avoid obfuscation. The basic premise is that, since learners, students, teachers and lecturers are not identical, one imposed type of education cannot suffice or succeed.

Looking at the high unemployment statistics among our youth, Respondent 2 said education must pay attention to the many work opportunities available but the scarcity of people with suitable skills to fill the positions. She said, "Provide trained vocational guidance counsellors from Grade 8 and into tertiary. There are students who do not know what a CA. is, saying that they want to be CA's!"

Respondent 7 said that the mission statements of provincial Departments of Education claim to value the individual but how can this be true of there is no differentiation and everyone is now "ordinary Grade”? She summed up, “At least, Ministers of Education, bring back streaming of students according to ability!”

When asked to clarify what she meant by "reality", she said that the actual abilities and talents of students must be identified and fostered, instead of a "one size fits all” approach. When asked to elaborate, she continued:

"I would blame the lack of subject specialists at the primary schools ... you must have a Mathematics primary school teacher, you must have an English expert who is trained for teaching English in primary schools.” (Respondent’s emphasis).

The authors are aware that this comment may be construed as elitist or racist but the context of the question remains differentiation i.e. use the skills and talents of all educators fully.

Respondent 14 said it is important to differentiate at university level too and that the focus needs to shift to include practical skills because, if not, "I am worried that dumbing down is going to become a reality [at tertiary level too]”. He cited the pre-OBE technicians as models of the balance between theory and practice. Currently, he stated, "You go to university after Matric or there is nothing for you".

A range of interesting other strategies was raised, for example, building actual schools instead of overcrowding existing ones; appointing qualified experts to mark Matric examinations and Department insisting that this, carefully mentored, form part of teacher training for new staff in secondary schools. These (and others) are beyond the scope of this article. 


\section{CONCLUSION}

The crisis in education in South Africa clearly needs to be addressed and it is the authors' belief that this article and thorough research and analysis involved is ground-breaking in its viewpoint approach. Further research needs to be done but this article provides insights, observations and experience which are collectively, thought-provoking and, we believe, of use to all involved in education.

This research engages 17 educators and parents in guided interviews. These reveal similar (if not identical) viewpoints focusing on the need for more research by the Department before introducing new education theories; expert professional training, both theoretical and practical, of teachers; the need for strong and consistent leadership at both national and school level. Many respondents also suggested thorough screening of applicants and the possibility of a professional entrance exam as a strategy for improving the education system. Emphasis was also placed on a need for many more actual hours of engagement between teacher/educator and student each week. The current situation, where trainee teachers engage for only three weeks a year was unanimously regarded as inadequate. This situation is leading to rehearsed lessons which give the false impression of the teacher's ability and expertise which are, in fact, lacking.

To address these negatives, increasing the profile and number of interns accepted in educational institutions and being mentored by top teachers working with them is seen as a potentially excellent solution. Many interviewees also indicated that the National Department of Education must strive to work with all stakeholders to create strong teams in support of learners as the mission statement of the Minister claims (Motshekga 2012). In particular, teachers feel strongly that basic issues (such as salaries and acceptable working hours) will go a long way to improve the status of the profession. Finally, the most repeated theme in all of the interviews was the belief that, if talented students are attracted to teaching/lecturing/educational research, the image of education as a career will be enhanced and this will be a powerful factor in better teaching and overall standards.

\section{NOTES}

1. Two of the stakeholders interviewed later in our research attended these camps in their Standard 5 (now Grade 7) and Standard 6 (now Grade 8) years.

2. Latin for "respect for the gods, dignity and decorum, and good citizenship".

3. This is according to Statistics South Africa.

4. Outcomes-based education (OBE) was introduced in 1997, and was reviewed in 2000 and 2009. This system, therefore, forms the foundation of all basic education and CAPS (Curriculum and Assessment Policy Statement) has now been fully rolled out. 
5. English Home Language policy document (CAPS).

6. English Home Language is now referred to as English First Language. Examining reasons for the change in terminology is beyond the scope of this article.

7. The lack of discipline was repeatedly raised in interviews but is beyond the scope of this article since it requires extensive research.

8. Educators and parents defined a strong foundation as the proverbial 3 R's strengthened by consistently endorsed rules and regulations.

9. Possible further research.

10. This is discussed in Strategies.

11. District office, GDE, Ekuhurleni.

12. First Language.

13. This was also applied to Maths.

14. Teacher selection and training, even at tertiary level, is stressed again and again.

15. The National policy is that a learner cannot be kept back more than once in each phase.

16. This refers to working through material to a correct answer, instead of rote learning.

\section{REFERENCES}

Alvesson, M. 2003. Beyond Neopositivists, romantics, and localists: A reflexive approach to interviews in organizational research. The Academy of Management Review 28(1): 13-33.

Atkins, J. and W. Maroun. 2015. Integrated reporting in South Africa in 2012: Perspectives from South African institutional investors. Meditari Accountancy Research 23(2): 197-221.

Carte Blance. 2012. Matric. Carte Blanche. March ed. South Africa: MNet.

Cary, M. 1976. A history of Rome. United Kingdom, Macmillan.

Creswell, J. 2009. Research design: Qualitative, quantitative, and mixed methods approaches. 3rd Edition. London, Sage Publications.

Crouch, L. and P. Vinjevold. 2006. South Africa: Access before quality, and what to do now. Profesorado. Revista de curriculm y formacion del profesorado 10(1): 15.

Dickens, C. 1850. David Copperfield. United Kingdom, Bantam Books, 1988.

Dilke, Q. A. W. 1976. The ancient Romans. How they lived and worked. United Kingdom, David and Charles.

Felton, S., T. Dimnik and M. Northey. 1995. A theory of reasoned action model of the chartered accountant career choice. Journal of Accounting Education 13(1): 1-19.

Foucault, M. 1983. Afterword: The subject and power. In Michel Foucault: Beyond structuralism and hermeneutics, ed. H. L. Dreyfus and P. Rabinow, 208-226. $2^{\text {nd }}$ Edition. Chicago, University Press.

Greenberg, R. K. and N. A. Wilner. 2015. Using concept maps to provide an integrative framework for teaching the cost or managerial accounting course. Journal of Accounting Education 33(1): 1635.

Guthrie, J., E. Evans and R. Burritt. 2014. Australian accounting academics: Challenges and possibilities. Meditari Accountancy Research 22(1): 20-37.

Holland, J. B. and P. Doran. 1998. Financial institutions, private acquisition of corporate information. European Journal of Finance 4(2): 129-155.

Hoskin, K. W. and R. H. Macve. 1986. Accounting and the examination: A genealogy of disciplinary power. Accounting, Organizations and Society 11(2): 105-136.

Hoskin, K. W. and R. H. Macve. 1988. The genesis of accountability: The west point connections. Accounting, Organizations and Society 13(1): 37-73. 
Jansen, J. 2012. Poliitcal theater means country praises medicrity. Saturday Star.

Lawrence, S. 2014. SUPER-VISION? Personal experiences of an accounting academicnull. Meditari Accountancy Research 22(1): 38-53.

Leedy, P. D. and Ormrod, J. E. 2001. Practical research: Planning and design. New Jersey, Prentice Hall.

Llewelyn, S. 1996. Theories for theorists or theories for practice? Liberating academic accounting research? Accounting, Auditing \& Accountability Journal 9(4): 112-117.

Llewelyn, S. 2003. What counts as "theory" in qualitative management and accounting research? Accounting, Auditing \& Accountability Journal 16(4): 662-708.

Malan, S. 2000. The "new paradigm" of outcomes-based education in perspective. Journal of Family Ecology and Consumer Sciences 28(1): 22-28.

Maroun, W. and J. Atkins. 2014. Whistle-blowing by external auditors in South Africa: Enclosure, efficient bodies and disciplinary power. Accounting, Auditing \& Accountability Journal 27(5): 834-862.

Martorell, G., D. Papalia and R. Feldman. 2013. A child's world: Infancy through adolescence. $13^{\text {th }}$ Edition. London, McGraw Hill Education.

Metcalfe, M., M. Orkin and G. Jenny. 2012. Our pass rate focus is too narrow. Sunday Times: 15 Jan, 2012: 6 .

Motshekga, A. 2012. English home language (First Language) Grades 10-12 policy document (CAPS). Pretoria: Government Printers.

Oakes, L., B. Townley and D. Cooper. 1998. Business planning as pedagogy: Language and control in a changing institutional field. Administrative Science Quarterly 43(2): 257-293.

Oosthuizen, M. and A. Cassim. 2016. The state of youth unemployment in South Africa. Applied Policy Research 1(June): 1-5.

Persson, M. and C. Napier. 2014. The Australian accounting academic in the 1950s: R. J. Chambers and networks of accounting research. Meditari Accountancy Research 22(1): 54-76.

Rowley, J. 2012. Conducting research interviews. Management Research Review 35(3): 260-271.

Singh, R. 2015. Current trends and challenges in South African higher education: Part 1. South African Journal of Higher Education 29(3): 1-7.

Tau, S. 2012. Focus on quality, not pass rate. The Citizen: 5 Jan, 2012: 6.

Wilmot, L. and A. Merino. 2015. A personal reflection of the impact of adopting a student-centred teaching approach to influence accounting students' approaches to learning. South African Journal of Higher Education 29(6): 257-274. 


\section{Appendix 1}

The following questions were included in the final interview agenda.

1. Why did you choose to become an educator?

2. Please state your highest level of education (for example, Senior Certificate, diploma, degree).

3. How many years have you been (or were you) employed in the education sector?

4. In which academic phase (for example, secondary) and position (for example, principal; tutor; coach) were/are you employed?

5. Briefly describe general educational standards in South Africa today (or you may answer concerning only the level you taught/teach).

6. What is your view of OBE as an educational system? Suggest the two most positive aspects of OBE. Suggest the two most negative aspects of OBE.

7. Since the introduction of CAPS and the subsequent $50 \%$ pass mark for English and Mathematics in grades 7, 8 and 9 (2014), have you seen changes in your students' standards of work, positive or negative? Please explain possible reasons for this.

8. A. If you teach/taught in the Internes phase, are/were you confident that your students are/ were well prepared and ready for secondary school at the end of Grade 7? Explain your response.

9. If you teach/taught in the FET phase, are/ were you confident that your students are/ were well prepared for tertiary education or training at the end of Grade 12? Explain your response.

10. If you teach/ taught at tertiary level, are/were you confident that your students are/ were well prepared for the challenges of tertiary education? Explain your response. Considering all the stakeholders in education, what theoretical and practical strategies do you recommend to ensure progress?

\section{Appendix 2: List of stakeholders/respondents}

\begin{tabular}{|c|c|c|}
\hline \# & Profile & Relevant experience \\
\hline 1 & Head of English Department in a government secondary school & 14 years \\
\hline 2 & Businessman and parent of Grade 12 student & 12 years \\
\hline 3 & $\begin{array}{l}\text { Draftswoman/educator in the foundation, intersen and secondary school } \\
\text { phases }\end{array}$ & 16 years \\
\hline 4 & $\begin{array}{l}\text { Educator in technology (Grade } 8 \text { to 10, pure Mathematics and AP } \\
\text { Mathematics) in a private secondary school }\end{array}$ & 10 years \\
\hline 5 & Educator in Mathematics (Grade 6 and 7) in a government school & 35 years \\
\hline 6 & University tutor and lecturer & 8 years \\
\hline 7 & Senior English educator in government and private schools & 17 years \\
\hline 8 & Principal of a government primary school & 30 years \\
\hline 9 & $\begin{array}{l}\text { Senior educator in Business Studies, Grade Head and Moderator of } \\
\text { NSC Examinations }\end{array}$ & 17 years \\
\hline 10 & $\begin{array}{l}\text { Educator in Afrikaans, Technology and Library Science in government } \\
\text { and private schools }\end{array}$ & 20 years \\
\hline 11 & $\begin{array}{l}\text { Senior History and Geography educator, Head of Department, Head of } \\
\text { Grade in a government secondary school and Deputy Chief Examiner } \\
\text { (Matric) }\end{array}$ & 26 years \\
\hline 12 & Educator in English (Grade 8-10) in a government school & 3 years \\
\hline 13 & Senior educator in pure Mathematics in private and government schools & 25 years \\
\hline 14 & $\begin{array}{l}\text { Assistant Dean, head of a literacy programme and parent of child in } \\
\text { primary school }\end{array}$ & 22 years \\
\hline 15 & Lecturer (and head of a teaching and learning group at tertiary level) & 11 years \\
\hline 16 & Principal of government secondary school & 21 years \\
\hline 17 & $\begin{array}{l}\text { Senior lecturer at a tertiary institution and parent of secondary and } \\
\text { primary school children }\end{array}$ & 9 years \\
\hline
\end{tabular}

